\title{
特発性側彎症における矢状面カーブの検討
}

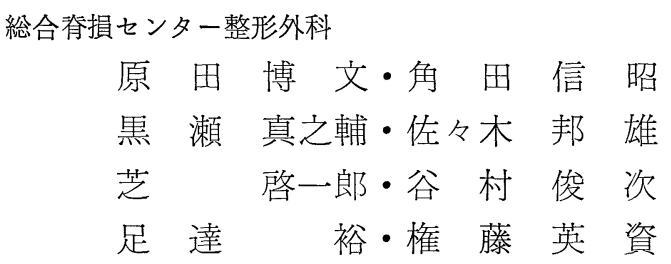

\section{Spinal Curvature on the Sagittal Plane in the Patients with Idiopathic Scoliosis}

by

\author{
H. Harada, N. Tsunoda, S. Kurose, K. Sasaki, K. Shiba, \\ S. Tanimura, Y. Adachi and E. Gondo \\ Department of Orthopaedic Surgery, Spinal Injuries Center, Iizuka
}

\begin{abstract}
It is well-known that the scoliotic spine has three deformities on each of its three orthogonal planes. A scoliosis with abnormality on the sagittal plane is called lordoscoliosis or kyphoscoliosis. But it is not well-known whether scoliosis is more often complicated with lordosis or kyphosis. We studied one hundred and two scoliotic spines with mild curvature of less than fifty degrees, and seventeen normal spines as controls. The scoliotic spines with thoracic curvature had less degree of thoracic kyphosis and more degree of lumbar lordosis than normal spines. We also estimated the sagittal curvature limited in the three apical vertebrae of the scoliotic spines. In the cases of thoracic curvatures these values were significantly correlated with the degree of curvature on the coronal plane.
\end{abstract}

㑡彎症は本質的には 3 次元変形であり, 前額面・矢 状面・横断面の 3 平面上に変形を有している. 乙の変 形を 3 次元的にとらえようとする報告も多いが，まだ 十分に解明されたとは言えない。わ和机は側彎症に おける矢状面カーブが，治療上において重要な意義を 有し，注意を要するととを述べてきた。しかしながら 「前額面と矢状面のカーブパターンに関連があるか否 か」,「前額面上の Cobb 角と矢状面上のカーブ角度は 相関するか.すなわち側彎の増強とともに前彎度は増 加すると言えるか」,「側彎の大きさと腰椎前彎度の関 連・胸椎部側彎の腰椎前彎度に及ぼす影響」など多く の疑問が残っている。今回われわれは側彎症の前額面 カーブと矢状面カーブの関連性について, 上記観点か ら检討を加えた。症例は特発性側彎症のみとし, 脊椎 の回旋の影響を少なくするために, 中程度から軽度力 ーブに限定した.
方法

症例は 1979 年から 1982 年までの当院開設以来 3 年 間に外来を受診した側彎症 206 名中, $20^{\circ}$ から $50^{\circ}$ ま での Cobb 角を有する特発性側彎症 84 例に $10^{\circ}$ 未満 の Cobb 角を有する機能性側彎 18 例を加えた 102 例 である. Cobb 角の大きさは $0 \sim 10^{\circ}$ 例 18 例, $10^{\circ} \sim$ $20^{\circ}$ 例 23 例, $20^{\circ} \sim 30^{\circ}$ 例 22 例, $30^{\circ} \sim 40^{\circ}$ 例 28 例, $40^{\circ} \sim 50^{\circ}$ 例 11 例である。コントロール群として全く正 常像を呈した 17 例を用いた. 男 30 例, 女 89 例で男 女比は女が多かった. 年令は 4 才から 42 才までの平 均 13.7 才であった. 側彎の大きさでカーブを分類す る場合, Single Curve の場合はその Cobb 角で, カ ーブが 2 つ以上存在する場合は, カーブの内大きい方 のカーブをその症例の側彎の大きさとした. 更にてれ らの内, 20 ํ上小側彎を有する症例を主カーブの位 
置により, $\mathrm{T}$ 型 (胸椎部), $\mathrm{TL}$ 型 (胸腰椎部), $\mathrm{L}$ 型 腰椎部), に分類した. Double Curve を有する例は, 双方共に胸椎にある場合 $\mathrm{T} ・ \mathrm{~T}$ 型, 一方が胸椎一方 が胸腰椎にある場合 $\mathrm{T} ・ \mathrm{TL}$ 型, 一方が胸椎一方が腰 椎にある場合 $\mathrm{T} ・ \mathrm{~L}$ 型とした. 矢状面カーブの測定 は Cobb 法に準じて行なった. 测定は (1) 胸椎後彎, (2) 腰椎前彎, (3) 側彎の主カーブの範囲内の矢状面 カーブ, (4) 側彎の主カーブの頂椎部 3 椎間に限定し た矢状面カーブの 4 つを各症例について行なった. 胸 椎後彎・腰椎前彎の測定は, 最も乙れらの角度が大き くなるようにカーブ範囲をきめて行なった，胸椎後彎 の上端は $\mathrm{T}_{3}$ むしくは $\mathrm{T}_{4}$, 胸椎後彎下端（腰椎前彎 上端に等しい）は $\mathrm{T}_{12}$ あしくは $\mathrm{L}_{1}$ が最あ多かった. 腰椎前彎下端部は第 5 腰椎ときめた. 側彎の主力カー ブ部分の矢状面カーブの測定範囲は, 側彎主カーブの 範囲とし, Double Cuve の場合は, 双方を含めた範 囲を測定した. 頂椎部 3 椎間の矢状面カーブあ各側彎 の主カーブ部分について，それぞれ測定した.

\section{結 果}

胸椎後彎・腰椎前彎度の変化を 調べるために, $10^{\circ}$ 毎に側彎 Cobb 角の大きさで分類した各群と正常を 比較し, 各胸椎後彎・腰椎前彎角の大きさについて T 検定を行なった. また $20^{\circ}$ 以上の側彎例をカーブの存 する部位別に分類し, 各群について正常群との間に有 意差があるかどうか比較 T検定を行なった. カーブの 存する部位別に分類した各群について，側彎カーブの 大きさと胸椎後彎度の相関係数, 側彎カーブの大きさ と腰椎前彎度との相関係数を求めた。 また相関の有意 性についてT検定を行なった．また矢状面カーブの測 定を主カーブ 3 椎間に限定し，その矢状面カーブの大 きさ (後彎角) と側彎角の大きさとの相関係数を求 め, 同様に有意性を調べた. 以上の結果を (1) 胸椎後 彎，（2）腰椎前彎，（3）側彎カーブ範囲内の矢状面力 ーブ,（4）側彎主カーブの頂椎部 3 椎間の矢状面カー ブの頂に分けて述べる.

(1) 胸椎後彎について

正常群と $10^{\circ}$ 毎に側彎 Cobb 角で分類した各群と の比較では, $10^{\circ}$ 未満群及び $40^{\circ} \sim 50^{\circ}$ の群では, (胸 椎後彎度に）正常群との間に有意の差はないすのの， 胸椎後彎は側彎群で減少する傾向がみられた. 10〜 $20^{\circ}$ の群, $20^{\circ}$ 〜 $30^{\circ}$ の群では, 有意の 減少がみられ た.この比較では, 側彎角の増大が胸椎後彎の減少と
相関するような傾向はみられなかった.

カーブの存する部位によるタイプ別の比較では, 胸 椎部に主力カーブを有する例すなわち $\mathrm{T}$ 型, $\mathrm{T} ・ \mathrm{~T}$ 型, $\mathrm{T} ・ \mathrm{~L}$ 型の各群に拉いて, 正常群も比べて有意の 胸椎後彎角の減少がみられた. これに対して胸椎部に おける側彎の少ない群すなわち $\mathrm{T} ・ \mathrm{TL}$ 型, TL 型で は, 正常群との間に有意差はなく, 胸椎後彎は減少の 傾向を示したのみであった.との各側彎タイプ別（部 位別) に側彎主カーブの大きさと, 胸椎後彎度の相関 係数を求めること, $\mathrm{T}$ 型 $-0.058, \mathrm{~T} ・ \mathrm{~T}$ 型 -0.056 , $\mathrm{T} ・ \mathrm{~L}$ 型 0.28 であり, 全例において相関に有意性は 得られなかった.

(2) 腰椎前彎について

正常群と $10^{\circ}$ 毎に側彎角で分類した各側彎群との比 較では，側彎 $10^{\circ}$ 未満では正常群との間に有意差をみ なかったのに対して, $10^{\circ} \sim 20^{\circ}$ 群 $(\mathrm{p}<0.05), 30^{\circ} \sim$ $40^{\circ}$ 群 $(\mathrm{p}<0.05), 40^{\circ} \sim 50^{\circ}$ 群 $(\mathrm{p}<0.01)$ におい て側彎群に有意の腰椎前彎の増大がみられた. $20^{\circ} \sim$ $30^{\circ}$ 群ではかなり腰椎前彎が増大しているものの, 正 常群との比較において有意水準 $5 \%$ に達しなかった. カーブタイプ別の比較では $\mathrm{T}$ 型, $\mathrm{T} ・ \mathrm{~T}$ 型, $\mathrm{T} ・ \mathrm{~L}$ 型 その他の全群において, 正常群と比べて腰椎前彎は有 意に増大していた. 各タイプ群における腰椎前彎度と 側彎主カーブの大きさの相関係数は $\mathrm{T}$ 型 $0.12, \mathrm{~T} ・ \mathrm{~T}$ 型 $0.41, \mathrm{~T} \cdot \mathrm{L}$ 型 $-0.23, \mathrm{TL}$ 型 $+\mathrm{T} \cdot \mathrm{TL}$ 型 0.19 で，いずれも有意の相関は得られなかった（p> $0.05)$.

（3）側彎主カーブ範囲内の矢状面カーブについて そこで矢状面カーブの測定を側彎主カーブの範囲内 に限定し, 側彎角との相関を求めると, 胸椎部に主力 カーブを有する $\mathrm{T}$ 型, $\mathrm{T} ・ \mathrm{~T}$ 型, $\mathrm{T} ・ \mathrm{~L}$ 型の各群では, 矢状面と前額面カーブの大きさの相関係数はそれぞれ $-0.38,0.24,-0.21$ であり, $\mathrm{T} ・ \mathrm{~T}$ 型を除く他の 2 つは側彎角（前額面カーブ）の増大に伴い後彎が減少 する傾向が得られた．残る $\mathrm{T} ・ \mathrm{~T}$ 型であ側彎角を $40^{\circ}$ 未満に限定すると相関係数 -0.39 と同様の傾向が 得られた. 相関の有意性は $\mathrm{T}$ 型のみあったが $(\mathrm{p}<$ 0.05), 他の 2 つではなかった. TL 型+T・TL 型の 胸椎部カーブの少さい例では相関係数 -0.13 で相関 の傾向はみられなかった.

（4）側彎主カーブ頂椎部 3 椎間の矢状面カーブに ついて

側彎のある椎体全体の矢状面カーブを測定すると, 


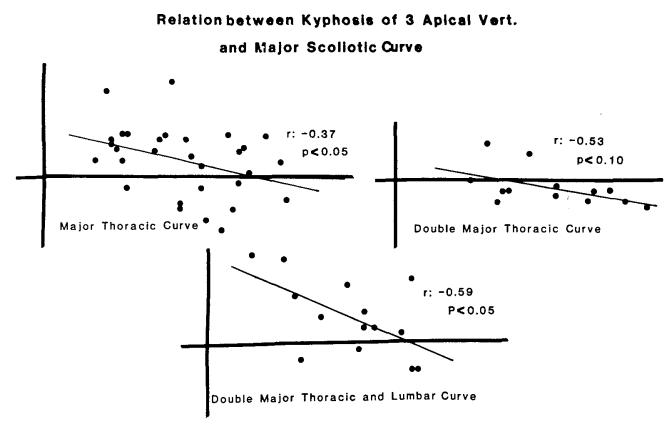

図 1 胸椎側彎角と頂椎 3 椎の胸椎後彎角の 関係（各侧彰の type 別）

頂椎部から離れた部分で側彎によって生じた前彎を代 償する可能性があるために，矢状面カーブの測定部を 更に頂椎部 3 椎間に限定した. すると矢状面・前額面 カーブの相関係数は $\mathrm{T}$ 型 $-0.37, \mathrm{~T} ・ \mathrm{~T}$ 型 -0.15 , $\mathrm{T} ・ \mathrm{~L}$ 型一0.59 となり，矢状面の測定を側彎部全 全 にわたってとるより増大した．相関の有意性は $\mathrm{T}$ 型 $(\mathrm{p}<0.05) ， \mathrm{~T} \cdot \mathrm{L}$ 型 $(\mathrm{p}<0.05)$ にて得られた.

$\mathrm{T} ・ \mathrm{~T}$ 型に㧍いても回旋の影響の大きい $40^{\circ}$ 以上例 を除くと，相関係数 -0.53 となり有意の相関 $(\mathrm{p}<$ 0.10）となる（図 1). TL 型+T・TL 型では相関係 数は一0.09であり 相関の傾向はなかった. 胸腰椎部 に頂椎を有する 10 例での検討では相関係数 -0.09 ( $\mathrm{p}>0.10)$, 腰椎部に頂椎を有する 16 例では相関 係 数一0.41（ $p>0.10 ）$ で，いづれも有意の相関は得ら れなかった. 各タイプ群に関係なく胸椎部にあるカー ブ 62 カーブについて，乙れらの相関を求めると相関 係数 $-0.48(\mathrm{p}<0.01)$ で有意水準は更に高まる（図 2).

\section{考 案}

Roaf (1966) は側彎症の initiating cause が何で あれ，できあがった側彎症においては，後方要素に比 べて前方要素が長くなることを指摘している．そして 後方要素に比した前方要素の伸長を前彎と呼ぶなら， 側彎症は本質的には前彎を伴うとし, 治療上その矯正 が重要であることを指摘している．Winter (1975) あまた特発性側彎症において, 胸椎部の前側彎 (lordoscoliosis）は，後側彎より Common であり，前 彎の大きい例は Milwaukee Brace での治療に反応 しにくく，またこのような例は呼吸機能障害む大きい と述べている. このため前彎を伴う例では観血的治療

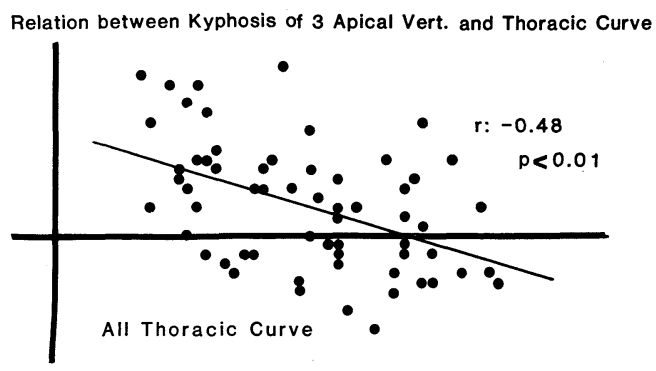

図2 胸椎部側彰角と頂椎 3 椎体の後彰角の関係

を推奨している．乙の点においてわれわれは以前観血 的治療群に括いても，胸椎部後彎が減少しているとと を報告した。 また観血的治療例の中でも，Distraction Rod と Compression Rod の併用群は, Distraction $\operatorname{Rod}$ のの群より, 胸椎後彎の減少が大き くなっており，観血治療において矢状面カーブの変 化，及び失状面カーブに対する治療に十分留意する必 要があることを述べた.（この場合は腰椎前彎も減少 して streight back になる傾向がある.)

今回は Milwaukee Brace むしくは，観血的治療 を行なう前の症例を中心として胸椎後彎の減少・腰椎 前彎の増大の程度を測定した．測定上の問題点として は，(1）まず矢状面上におけるカーブを単に前彎・後 彎と規定してよいのかという問題がある．乙れは側彎 には必ず回旋を伴うからである．（2）次に正常の前 彎・後彎は何度であり, 正常変曲点はごこであるか, （3）また頂椎 3 椎間のみの 矢状面カーブの測定の 場 合，その部分での正常後彎角は何度であるかの問題が ある. 以上の解決策として，（1）に対して，測定する 側彎症例をカーブの小さいむの（すなわち回旋も小さ いむの）とし，可及的に回旋の影響を少なくした． 従 ってあまり細かく側彎角・後彎角の回帰直線その他の 処理をするのは意味がないと考えられる．（2）に対し ては，同じような年令の正常群を対象例として比較し た.（3）各症例により側彎頂椎が異なるためコントロ ールがとりにくい，乙のため正常後彎角は求めず，矢 状面・冠面上のカーブが，正の相関を示すか負の相関 を示すか，または相関しないかで評価した。

頂椎部 3 椎に限局する矢状面・冠状面カーブは互い に相関するが，矢状面カーブを側彎カーブ全体にまで 大きくとると相関が悪くなってくる．乙れは $\mathrm{y}=\mathrm{a}(\mathrm{x}$ $\left.+e_{x}\right)+\left(b+e_{b}\right)$ と考えると矢状面测定範囲を広くと ることにより, $\left(b+e_{b}\right)$ の 部分が大きくなり相関が不 
明瞭となってくるものと考えられる。また頂椎部から 離れるに従って逆に代償性の後彎を呈してくること屯 考えられるであろう. いづれにせよ胸椎部では，側彎 頂椎部に拈いて後彎は減少しているととが示唆され る.

しかしながら高度カーブを論じる場合，回旋の影響 は無視できず, 前彎・後彎の定義を明確にする必要が あると共に，乙の回旋を補正しなければならない，乙 の場合 Roaf の指摘するように前方要素・後方 要素 の長さの比較が essential であるように思える. 2 方向撮影による 3 次元的な評価が必要となってくるで あろう，高度カーブに扔いては単なる矢状面カーブの 測定のみでは前彎・後彎は語れないととは注意を要す る.

\section{参 考 文 献}

1）志田原哲・他：特発性側彎症に招ける䠲柱矢状 面の彎曲について（第 1 報）．第15回 脊柱側彎症 研究会口演, 1981.

2) 角田信昭・他：脊柱側彎症飞対するHarrigton Instrumentation の矢状面彎曲汶対るす影響. 第15回脊柱側彎症研究会口演, 1981.

3) Moe, J. H. et al: Scoliosis and Other Spinal Deformities, Saunders, Philadelphia, 1978.
4) Roaf, R.: The Basic Anatomy of Scolisis, J. Bone and Joint Surg., 43-B : 786-792.

5) Takemitsu, Y. et al.: Mathematical Model of the Scolitic and Ryphoscol ticoicurue, Regarded as a Space Curue., Orthopaedic Transuction, 4: 31, 1980.

6) Winter, R. B. et al.: Excessive Thoracic Lordosis and Loss of Pulmonary Function in Patients with Idiopathic Scoliosis., J. Bone and Joint Surg., 57-A : 972-977, 1975.

\section{質 問 旭川医大整形外科 竹光 義治}

1. 後彎の減少と側彎の自然増悪と関係があるか否 かについて調へてておられたら拈教えいただきたい.

2. 側彎之後彎の頂点之は一致していないものが多 いと思うが，そのととと側彎角とは何か関係がありま したか.

解 答総合脊損センター 原田 博文

(1) 矢状面カーブに㧍ける後彎の減少と側彎の progression の関係は今回求めていない.

(2) 矢状面に求ける前彎の出現部位と側彎の頂椎と は必ずしも一致しない，しかし一致しない例でもす心゙ て頂椎部 3 椎に測定部位を一定化して統計的に関連を 求めた. 